Journal of

Business and Strategic

Management

(JBSM)

ENTREP

Daniel Karar

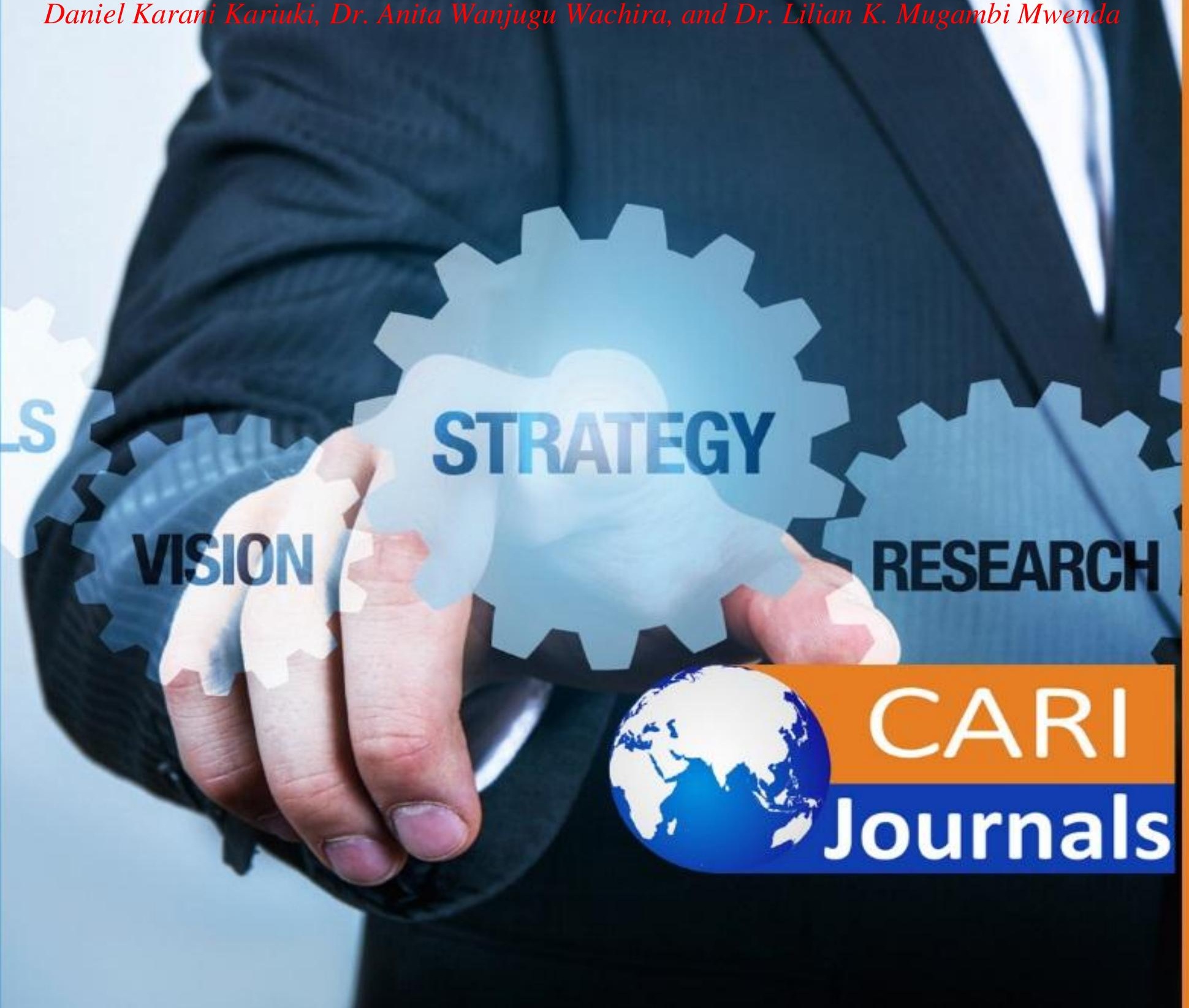




\title{
ENTREPRENEURIAL MINDSET AND INNOVATION BY 1-3 STAR RATED HOTELS IN KENYA
}

\author{
$1^{*}$ Daniel Karani Kariuki \\ Postgraduate Student: Business Management Department, School of Business Management and \\ Economics, Dedan Kimathi University of Technology \\ *Corresponding Author's E-mail: karanid2004@gmail.com \\ ${ }^{2}$ Dr. Anita Wanjugu Wachira \\ Business Management Department, School of Business Management and Economics, Dedan \\ Kimathi University of Technology \\ ${ }^{3}$ Dr. Lilian K. Mugambi Mwenda \\ Business Management Department, School of Business Management and Economics, Dedan \\ Kimathi University of Technology
}

\begin{abstract}
Purpose: The study aimed to assess the effect of entrepreneurial mindset on innovation by 1-3 star rated hotels in Kenya.

Methodology: This study considered positivism philosophy, quantitative measurement paradigm. The study targeted 111 hotels (1-3 star rated) through census, of which 3 respondents per hotel (CEO, Finance manager and Operations manager) were considered, from the hotels' list provided by the Kenya Tourism Regulatory Authority (TRA). A cross sectional survey was conducted where the self-administered questionnaire was used. Both the reliability and validity tests were done before the data analysis. The collected data was analyzed using descriptive and inferential statistics with the help of Excel and SPSS version 25.0. The hypotheses were presented and tested using multiple analysis and accepted at 95 percent confidence level.

Results: The findings revealed that entrepreneurial mindset and hotel innovation by 1-3 star rated hotels in Kenya are positively and significantly related $(\boldsymbol{\beta}=0.590, \mathrm{p}=0.020)$. This led to the rejection of the null hypothesis that; the effect of entrepreneurial mindset on innovation by 1-3 star rated hotels in Kenya is not statistically significant. Specifically, the study concludes that 1-3 star rated hotels in Kenya have strived to improve their innovative ability since they have shown consistency in seeking information on new business ideas in the hotel sector; access of information on new business ideas in the hotel sector; identifying and choosing most promising business opportunities and execution of the most promising business opportunity. In addition, the managers view changes in the hotel sector as precursors for new business opportunities implying the resilient entrepreneurial mindset.
\end{abstract}

Unique contribution to theory, policy and practice: Based on the study findings, the study also recommends the hotel entrepreneurs to be proactive in seeking new product ideas and customer product information which will in turn enable them create ideas on coming up with innovative products.

Keywords: Entrepreneurial mindset, innovation, 1-3 star rated hotels in Kenya 


\subsection{INTRODUCTION}

Innovation is currently a topic widely studied, mainly in the sectors of manufacturing, information technology and finance but little discussed or explored in the hotel industry (Meira, Anjos, \& Falaster, 2019). Furthermore, innovation is the ability to successfully implement new ideas, processes, products, or services, involving the capacity to change and adapt, and is characterized by everything that differs from ordinary business or which represents a discontinuity of a previous practice. The highly competitive environment of the hotel industry drives the search for strategies that would help introduce innovations which make hotels competitive. Where hotels face stiff competition, it is prudent for them to maintain their competitiveness by distinguishing themselves from others through continuous improvements and innovations. Study looking at 900 Swedish firms analyzing the difference between firm specific and location specific concluded that the most important characteristics that explain innovation lie within the firm itself and not the location of the firm (Backman, Johan \& Oner, 2017).

To address the competition challenge, hotels both collectively and individually will have to adopt a continuous innovation mode. According to Kaya (2015), innovation is a Latin word innavatus, which means to make something new and a product of efficiency and productivity in utilization of resources. Continuous innovation by hotels thus helps to counter the effects of eroded competitive advantages and this makes hotel innovation critical for the survival of individual enterprises and growth of the tourism industry in general. For this reason, hotel innovation activities have elicited scholarly interests across the discipline, with the aim of analyzing the nature, process and factors affecting innovation considering the dynamism in the tourism industry (Wanjiku, 2018).

Ertuna, Karatas-Ozkan, Yamak (2019) basing on the case studies covering Hilton Worldwide Holdings Inc. (Hilton), its Turkish subsidiary and a local hotel chain, indicate that local affiliate hotels always seek to acquire local legitimacy in their host environment, despite a standard format imposed by their headquarters. Local necessities and priorities translate themselves into such initiatives in a very limited way in the affiliates of the Hilton where there is mostly a topdown approach. Places of best practice might inspire Rwandan firms to improve their tourism services. The Rwandan government has taken positive steps to push internet access in hotels, and to give support when problems occur (Foster \& Graham, 2015). Amidst the Covid-19 Shock, Rwanda has shown resilience and exquisite application of innovative strategies to keep their hotel industry performance afloat. The Rwanda Development Board (RDB), Private Sector Federation (PSF) ICT and Tourism Chambers in June, 2020 hosted an online conversation and workshop to identify innovations and solutions the technology sector currently has, or could build to support the recovery process (Sabiiti, 2020).

Thus, for the firm to turn the discovered opportunities into a sustainable competitive advantage, the entrepreneurs' entrepreneurial mindset should permeate to the rest of the firm by inculcating entrepreneurial culture and leadership which in turn facilitate strategic management of the firms' resources and alignment of processes and structures towards the firms' strategies (Sudrajat, 2015). The level of hotels' innovation in Kenya can therefore, be understood through assessing the hotels employees' entrepreneurial mindset and how it is harmonized to yield competitive advantage (Dzhandzhugazova et al., 2016). 


\subsection{Statement of the problem}

Innovation drives hotel competitiveness (Baporikar, 2014), in turn improving visitors' destination which directly and through multiplier effect contributes to improved GDP, increased foreign exchange earnings, improved tax revenue collection by the exchequer and the job creation thus, improving economic stability and thus reducing poverty (Murimi, Moses \& Eric, 2019).

Findings from other studies (Mattson et al., 2014, Wandongo et al., 2010), reveal that the hotel sector has relatively low innovation orientation. Tourists' arrival in Kenya has also been declining as Kenya loses its market share to less endowed destinations mainly due to lack of innovation in line with global trends (World Bank, 2018). The hotels are considered rigid and non-innovative (Wikhamn, Armbrecht \& Wikhamn, 2018) and that they lack explicit innovation strategy and only half of them produce at least one type of innovation. Lower category hotels are less innovative than higher category hotels (Murimi et al., (2019). This is evident from low level of research and development (R\&D) in hotel establishments (Orfila-Sintes, Crespi-Cladera and Martínez-Roe, 2005). If this low performance trend is not urgently addressed, Kenya's economic performance will continue to be affected negatively, leading to increased poverty levels and other subsequent ills such as insecurity. From the reviewed literature, (Mattson et al., 2014, Wandango et al., 2010, Adamako, Danso, Boso and Narteh, 2018), little has been done on innovation and its drivers by hotels. The studies previously carried out on innovation were mainly in the areas of leadership and academic entrepreneurship, information technology, finance, and manufacturing. Thus, none of these studies addressed the role of entrepreneurial strategies as drivers of hotel innovation. This study seeks to fill in the gaps in the body of knowledge.

This study therefore reports that the 1- 3 star rated hotels in Kenya need innovation in their service provision as anchored on four theories; Entrepreneurial Orientation Theory, Dynamic capability theory, Technology Acceptance Model (TAM) and the Social Cognitive Theory, with Entrepreneurial Orientation Theory as the main theory. To help the hotels survive this hyper competition, this study proposes to assess the effects of entrepreneurial mindset, culture and leadership strategies and strategic organizational resources management as drivers of innovation by 1-3 star rated hotels in Kenya and to make recommendation thereof on how to adopt the strategies as a way of improving the hotels competitive edge.

\subsection{Purpose of the study}

The main purpose of this study was to effect of entrepreneurial mindset on innovation by 1-3 star rated hotels in Kenya.

\subsection{Research Hypothesis}

Ho: The effect of Entrepreneurial mindset on innovation by 1-3 stars rated hotels in Kenya is not statistically significant.

\subsection{LITERATURE REVIEW}

\subsection{Theoretical Review}

\subsubsection{Entrepreneurial Orientation Theory}

It is Covin and Slevin (1989) who came up with Entrepreneurial Orientation (EO) in their orientation model of 1989. This model was based on Khandwalla (1977) and Miller and Friesen 
(1982) earlier work. In coming up with this model, Covin and Slevin (1989) theorized that Entrepreneurial orientation (EO) dimensions were risk taking, innovation, and pro-activeness which interact and form strategic orientation. According to Covin and Slevin (1989), aggregating these dimensions will help research in the area of entrepreneurship. The theory also builds up from the Schumpeterian theory of innovation, as well as Kirzner (1997) whose perspective on the firm's entrepreneurial theory was based on the competitive market process.

According to this theory, different individual responses towards entrepreneurial activities are caused by different factors. That is, individual psychological traits include high achievement need, foresight or vision, ability to face opposition, pro-activeness, aggressiveness, and creativity (Phan, 2004; Schumpeter, 1934). Alertness to changes in the environment, superior intelligence, good judgment and good decision-making tendencies are other traits (Katz \& Gartner, 1988). Schumpeter brought an innovation approach that had ignored the aspect of risk-taking function of the entrepreneur, which is critical and should not be ignored as there is enough risk involved, every time an entrepreneur develops a new combination of factors of production (Lumpkin \& Dess, 1996).

Rauch, Wiklund, Lumpkin and Frese, (2009) found that EO and firm innovation, were strongly related. Wang (2008), posits that EO as put by Lumpkin and Dess (1996), is the decision-making activities, strategies, and processes, that lead to new entry and that entrepreneurial firm is one that undertakes somewhat risky ventures, engages in product-market innovation, and is first to come up with 'proactive' innovations, and being ahead of competitors. Going by Marx (1973) and Bober (1965) the theory over emphasizes on innovative functions of the entrepreneur whereas ignoring the organizing aspects of entrepreneurship. As one of the instrumental theories in the current study, the Entrepreneurial Orientation Theory has provided considerable theoretical evidence towards the mindset of the entrepreneur in the hotel industry.

\subsection{Empirical Review}

\subsubsection{Entrepreneurial Mindset and Hotel Innovation}

Entrepreneurial mindset refers to the attributes that distinguish between entrepreneurs and nonentrepreneurs; these are the combined intentions, thought processes, and skills. It is a product of meta-cognitive awareness. It is also the capacity to identify the changing environment and demands, adjusting the thinking process and equipping oneself with the appropriate skills. Davis et al. (2016) improved their entrepreneurial mindset definition to mean the capacity to quickly identify, act and bring together the available resources, exploiting the available opportunities while making the decision under uncertainty. To McMullen and kier (2016), entrepreneurial mindset is the capacity to identify the opportunities and to optimize them disregarding the limitation of current available resources.

Lack of awareness on the nature of entrepreneurship training has become problematic with growing efforts to educate potential entrepreneurs, and with policy makers who encourage educators to use entrepreneurial learning to promote young people's entrepreneurial characteristics and behaviors (Naia, Baptista, Januário \& Trigo, 2014; Rae \& Wang, 2015). Therefore, based on the fact that many studies have stressed on the impact recognizing opportunities and/or threats, entrepreneurial framework and entrepreneurial alertness, the current study therefore digs deeper into the aspects to find their influence in the Kenyan hotel industry. 


\subsubsection{Recognizing opportunities}

Recognizing opportunities refers to the aspect where business owners find gaps in established markets. It depends on the individual's ability to identify and link patterns (Karlesky, 2015). Based on the theory that actors in a free market have imperfect and/or asymmetric information Ebner, A. (2005), innovative entrepreneurs will always be on the lookout for new and workable opportunities that others might not see.

\subsubsection{Entrepreneurial alertness}

This is consistent with the entrepreneurial alertness which refers to the opportunity identification process that is the process of finding new business opportunities in the competitive market. Yet this relationship remains largely unverified by empirical evidence (Cox, 2016). Entrepreneurial alertness has been consistently conceptualized as an important antecedent to opportunity identification (Ardichvili et al., 2003; Gaglio \& Katz, 2001).

\subsubsection{Entrepreneurial framework}

Entrepreneurial framework refers to the guideline developed to depict the phenomenon of the establishment and operation of entrepreneurial teams. It is the result of the relations of a variety of factors with an effort to define the six key variables: process, the entrepreneur, the environment, market idea, capital and context of the company (Lucky \& Minai, 2011).

In Ghana, Adomako, Danso, Boso, and Narteh, (2018) analyzed the relationship between alertness of the entrepreneur and new organization innovation and the aiding roles of networking capability. A random sample of 930 new firms was selected to participate in the study. Primary data collected from 203 new firms operating in Sub-Saharan African economy, Ghana was used for this study. With regard to innovative strategies, this study can be replicated to other social and economic contexts, similar to Ghana. Since Ghana shares many characteristics with Kenya, the study is suitable to test the impacts of entrepreneurial alertness on firm innovation in developing countries. The study largely borrows from the resource-based view theory, a strong theoretical point of view that forms a strong background for the study. The study is however limited in a number of ways. The use of the primary data only limits the study to the data at a given point in time and this predisposes the research to subjective responses rather than objective responses. The current study introduces quantitative metrics that can be measured in order to justify the respondents' responses in the questionnaire and thus improves the study's rigor and robustness as well as improving the objectivity of the research instrument.

In Kenya, Njeru (2012) investigated the levels of entrepreneurial mindset by small manufacturing firms in industrial Area, Nairobi Kenya and its effect on the innovation. The study looked into 230 manufacturing firms in Industrial Area Nairobi Kenya. The dependent variable was firm innovation (profitability, market share and expansion), while the independent variables were entrepreneurial mindset (creativity, business alertness and innovativeness). The researcher used exploratory research. The study was hinged on the Schumpeterian theory on innovation, The McClelland motivation theory and entrepreneurship theory. To get quantifiable relationships, quantitative strategies were used and thus the study benefited by using quantitative approach which helped the study to research on the problem. Small and medium sized manufacturing firms in Nairobi Industrial Area which were distributed across six sectors and were involved in the production and distribution processes were used as target population. 
A two-stage sampling approach, which was first stratified and later randomized, was used. The research instrument, used was two hundred and thirty questionnaires. The study questionnaire was well formatted to capture objective responses from the sample. However, despite the advantages brought about by the quantitative study, the study lacked insightful opinions from the study population since the questions were rigid to a specific kind of response. The use of qualitative data in the study could have reinforced the findings of the study and improved the robustness of the responses (Njeru, 2012). The methodology however did not draw from a philosophical point of view and thus lacks an informative approach/baseline to the research design. The current study thus offered to fill the existing gap by improving on the methodological aspects where the data was both quantitative and qualitative. The study's focus on small firms and manufacturing offers mere generalities, given the ambiguity of small firms in different industries. Instead, categorizing of firms on the basis of innovation indicators whether large or small is a more appropriate and relevant focus. Thus, this study intends to categorize the hotels according to their star rating, their level of innovation and in terms of offering quality and standard services. The study considered (1-3) star rated hotels.

The study, however, left out the contribution of the legal environment towards the success of innovation in the industry, thus this study incorporates the effect of the Public Health Policy Compliance as a moderating variable in the hypothesized relationship. Nevertheless, Njeru (2012) indicated that there was a positive relationship between business alertness and business performance. There was also notable relationship between Entrepreneurs' characteristic (gender) and innovativeness, creativity and business alertness and a positive relationship between innovativeness and business performance.

\subsection{Operational Framework}

The researcher developed measuring parameters of innovation by 1-3 star rated hotels in Kenya being the dependent variable, entrepreneurial mindset as independent variable. The entrepreneurial mindset measurements involved rating the opportunity recognizing skills, level of alertness to market changes and the ability in analysis and choice of the most beneficial business opportunity through real options logic. In addition, the mindset dimension was assessed through the readiness of the hotel's entrepreneur to communicate nature, goals, time plan and benefits of the discovered opportunity to the rest of the hotel employees and stakeholders.

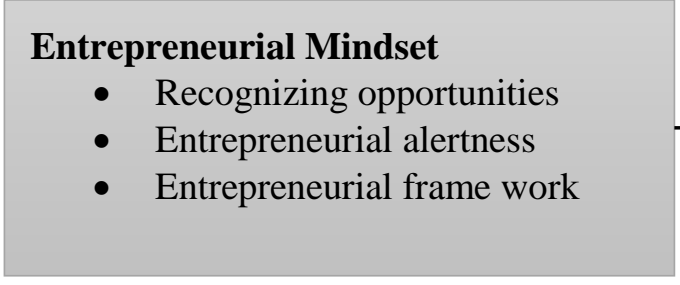

Independent Variables
Innovation by 1-3 Star rated Hotels in Kenya

- New products and services

- New processes

- Amount invested in R\&D

Dependent variable

Figure 1: Operational Framework 


\subsection{RESEARCH METHODOLOGY}

This study considered positivism philosophy, quantitative measurement paradigm. The study targeted 111 hotels (1-3 star rated) through census, of which 3 respondents per hotel (CEO, Finance manager and Operations manager) were considered, from the hotels' list provided by the Kenya Tourism Regulatory Authority (TRA). A cross sectional survey was conducted where the self-administered questionnaire was used. Both the reliability and validity tests were done before the data analysis. The collected data was analyzed using descriptive and inferential statistics with the help of Excel and SPSS version 25.0. The hypotheses were presented and tested using multiple analysis and accepted at 95 percent confidence level.

\subsection{FINDINGS AND PRESENTATION}

\subsection{Response rate}

The results in Table 1 give the level of respondents' cooperation on their view regarding the questions asked.

\section{Table 1: Response Rate}

\begin{tabular}{lcc}
\hline Response & Frequency & Percentage \\
\hline Returned & 239 & $72 \%$ \\
Unreturned & 94 & $28 \%$ \\
Total & $\mathbf{3 3 3}$ & $100 \%$ \\
\hline
\end{tabular}

The total questionnaires given were 333 of which 239 were properly filled and returned. The return of these questionnaires was $72 \%$ of the total questionnaires given out, thus meeting the threshold of Allen (2016) and also Rindfuss (2015), who posit that a response rate of above 50\% is adequate for a descriptive study.

\subsection{Pilot results}

\subsubsection{Reliability results}

The research instrument's reliability test was done using Cronbach's alpha. This yielded Cronbach's alpha values of above 0.7 for all the study variables, thus the results were acceptable as per the thresh holds given by Sekaran and Bougie (2019) who stated that coefficient greater than or equal to 0.7 is acceptable for basic research. Safari and Akpunar (2020) explain that reliability can be seen from two sides: reliability (the extent of accuracy) and unreliability (the extent of inaccuracy.

\section{Table 2: Reliability Results}

\begin{tabular}{lcc}
\hline Variables & Cronbach's Alpha & Conclusion \\
\hline Hotel innovation & 0.773 & Reliable \\
Entrepreneurial Mindset & 0.740 & Reliable \\
\hline
\end{tabular}

The pilot results proved that the variables statements were highly reliable with Cronbach's Alpha for the results being 0.740 and 0.773 for Entrepreneurial Mindset and Hotel innovation respectively. 


\subsubsection{Construct Validity results}

Factor analysis was used to test for construct validity performed using Kaiser-Meyer-Olkin (KMO) with interpretive adjectives for the KMO. The instrument was discussed with the supervisors from the Dedan Kimathi University of Technology who provided expertise and ensured the questions in the questionnaires measured the study variables. The KMO test has the following KMO Value/Degree of Common Variance: 0.00 to 0.49 unacceptable, 0.50 to 0.59 miserable, 0.60 to 0.69 mediocre, 0.70 to 0.79 middling, 0.80 to 0.89 meritorious and 0.90 to 1.00 marvellous (Simon \& Goes, 2016).

Table 3: Factorial Test Results for Construct Validity

\begin{tabular}{|c|c|c|c|c|c|c|}
\hline \multirow[b]{2}{*}{ Variable } & \multirow[t]{2}{*}{ KMO } & \multicolumn{3}{|c|}{ Bartlett's Test of Sphericity } & \multirow[t]{2}{*}{ Conclusion } & \multirow[t]{2}{*}{ Validity } \\
\hline & & $\begin{array}{l}\text { Approx. Chi- } \\
\text { Square }\end{array}$ & df & Sig. & & \\
\hline Hotel innovat & 0.510 & 61.097 & 32 & 0.006 & & Valid \\
\hline Entrepreneurial Mindset & 0.606 & 54.408 & 32 & 0.025 & mediocre & Valid \\
\hline
\end{tabular}

KMO Bartlett's test for sphericity was done and yielded the following results, entrepreneurial mindset $(\mathrm{KMO}=0.606, \mathrm{p}=0.025)$ and hotel innovation $(\mathrm{KMO}=0.510, \mathrm{p}=0.006)$ which indicated a significant sampling adequacy for the dependent and independent variables (Table 3 ).

\subsection{Descriptive statistics for Entrepreneurial Mindset and Hotel Innovation}

The first study objective was to assess the effect of entrepreneurial mindset on innovation by 1-3 star rated hotels in Kenya. The respondents were asked to indicate the extent to which the hotel has engaged in the following aspects on entrepreneurial mindset from 2018 to 2020. Their responses were averaged as shown in Table 4:

Table 4: Entrepreneurial Mindset Performance 2018 to 2020

\begin{tabular}{cccc}
\hline Year & $\begin{array}{c}\text { Number of internal } \\
\text { meetings to discuss new } \\
\text { business ideas }\end{array}$ & $\begin{array}{c}\text { Number of } \\
\text { entrepreneurial } \\
\text { conferences attended }\end{array}$ & $\begin{array}{c}\text { Number of staff dedicated } \\
\text { to monitoring and } \\
\text { evaluation process }\end{array}$ \\
\hline 2018 & 20 & 5 & 7 \\
2019 & 18 & 5 & 7 \\
2020 & 20 & 5 & 8 \\
\hline
\end{tabular}

Table 4 indicates that on average, 1-3 Star Rated Hotels in Kenya had about 20 internal meetings to discuss new business ideas per year, 5 entrepreneurial conferences attended per year and 7 staff dedicated to monitoring and evaluation process. The number of internal meetings to discuss new business ideas on average increased from 18 to 20 and this is attributed to the COVID-19 pandemic where the managers needed to re-strategize on the approach to maintain their businesses afloat given that the hospitality industry was severely hit by the policy on social distancing and working from home. The number of entrepreneurial conferences attended by the hotel staff remained an average of 5 whereas the number of staff dedicated to monitoring and evaluation process increased to 8 . The respondents were further asked to indicate whether they agreed or disagreed with the following statements relating to entrepreneurial mindset and hotel innovation by 1-3 star rated hotels in Kenya. The conclusions on the Likert responses were made 
by combining SD and D to imply disagreement, NS to imply neutral decision and A, and SA to imply agreement. The results are as shown in the Table 5:

Table 5: Entrepreneurial Mindset in Percentages, means and standard deviations

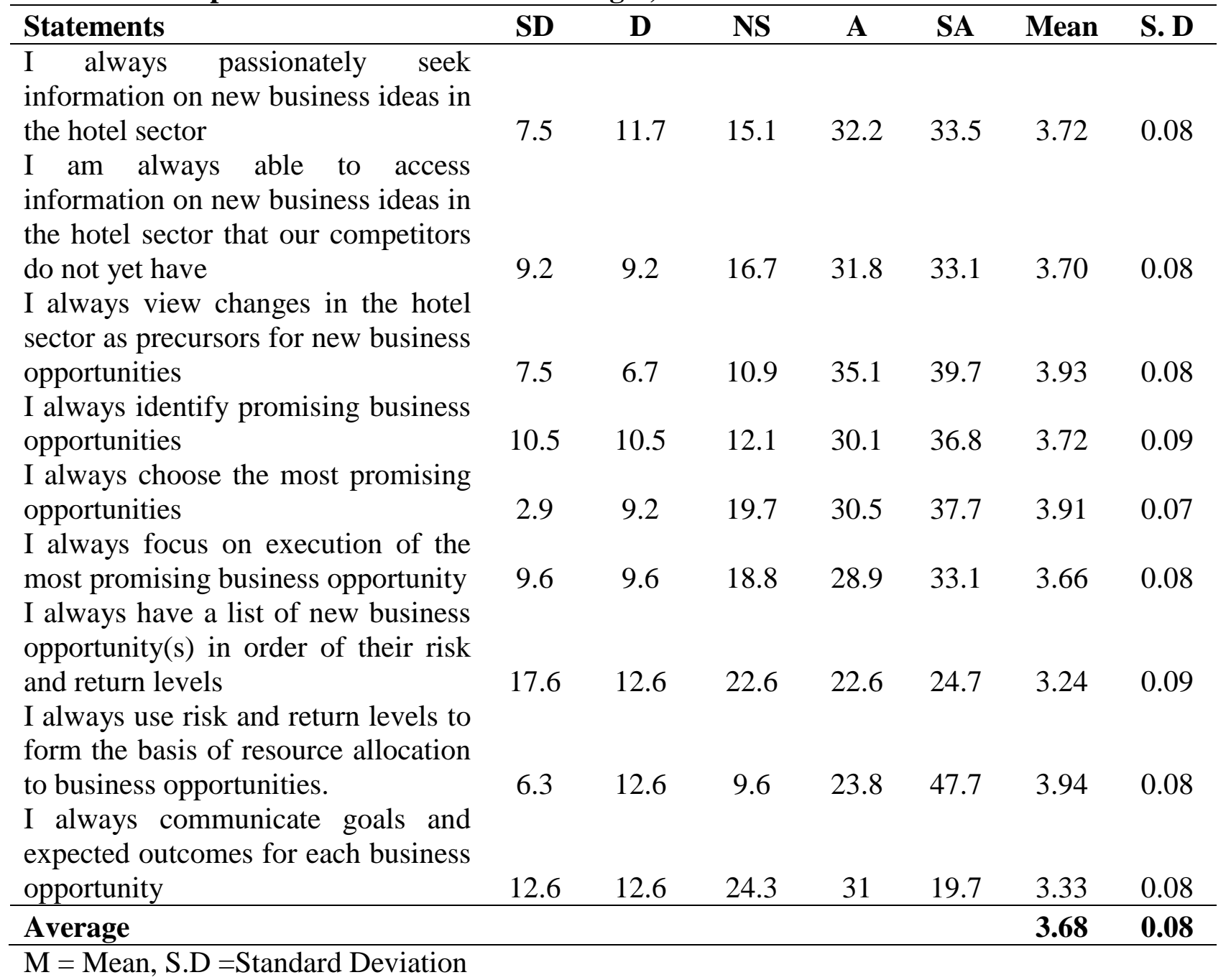

The results in the Table 5 revealed that majority of the respondents $(65.7 \%)$ always passionately seek information on new business ideas in the hotel sector (mean $=3.72 \approx 4$ ). This implies that on a scale of 1 to 5 (where 1 is strongly disagree and 5 is strongly agree), on average, the respondents indicated agreement. The results further indicate that, $64.9 \%$ of the respondents agreed that they are always able to access information on new business ideas in the hotel sector that their competitors do not yet have (mean $=3.70 \approx 4)$. This implies that on a scale of 1 to 5 (where 1 is strongly disagree and 5 is strongly agree), on average, the respondents indicated agreement. $74.8 \%$ of the respondents agreed that they always view changes in the hotel sector as precursors for new business opportunities (mean $=3.93 \approx 4$ ). This implies that on a scale of 1 to 5 (where 1 is strongly disagree and 5 is strongly agree), on average, the respondents indicated agreement. In addition, $66.9 \%$ of the respondents agreed that they always identify promising business opportunities (mean $=3.72 \approx 4$ ). This implies that on a scale of 1 to 5 (where 1 is strongly disagree and 5 is strongly agree), on average, the respondents indicated agreement. The 
results likewise, showed that $68.2 \%$ of the respondents agreed that they always choose the most promising opportunities (mean $=3.91 \approx 4$ ). This implies that on a scale of 1 to 5 (where 1 is strongly disagree and 5 is strongly agree), on average, the respondents indicated agreement. The results further show that, $62.0 \%$ of the respondents agreed that they always focus on execution of the most promising business opportunity (mean $=3.66 \approx 4$ ). This implies that on a scale of 1 to 5 (where 1 is strongly disagree and 5 is strongly agree), on average, the respondents indicated agreement.

The results also exposed that $47.3 \%$ of the respondents agreed that they always have a list of new business opportunity(s) in order of their risk and return levels (mean $=3.24 \approx 4)$. This implies that on a scale of 1 to 5 (where 1 is strongly disagree and 5 is strongly agree), on average, the respondents indicated agreement. The results also showed that $71.5 \%$ of the respondents agreed that they always use risk and return levels to form the basis of resource allocation to business opportunities (mean $=3.94 \approx 4$ ). This implies that on a scale of 1 to 5 (where 1 is strongly disagree and 5 is strongly agree), on average, the respondents indicated agreement. Besides, $50.7 \%$ of the respondents agreed that they always communicate goals and expected outcomes for each business opportunity (mean $=3.33 \approx 4$ ). This implies that on a scale of 1 to 5 (where 1 is strongly disagree and 5 is strongly agree), on average, the respondents indicated agreement. In summary, the average mean of the responses was 3.68 with a standard deviation of 0.08 . On a scale of five points, this means that majority of the respondents described themselves as being entrepreneurial minded towards hotel innovation by 1-3 Star Rated Hotels in Kenya.

The low standard deviation close to zero implies that the data points are closely clustered to the mean. The mean of 3.68 implies that the hotel entrepreneurs are vigorous in trying as much to foster their mindset towards a futuristic business. Given the statement in the Table 5, the entrepreneurs make efforts to strategize innovatively; however, the strategies they use have not made them reach a competitive scale yet. Table 6 gives statements to answer the open-ended question on respondents' opinions on other ways they describe themselves as having entrepreneurial mindset.

The findings are consistent with previous findings indicating that entrepreneurial spirit fosters the development and enhancement of innovative skills (Alnawas \& Hemsley-Brown 2019; Ghantous \& Alnawas, 2020). Indeed, market orientation has an effect on the project capability since it allows for the advancement of promotional competencies and the achievement of positive marketing achievements (Revilla-Camacho et al., 2020). Additionally, other characteristics such as collaborative partnerships (Pongsathornwiwat et al., 2019) and learning orientation (Nair, 2019) boost organizational innovation capabilities. Likewise, according to Jemal (2020), entrepreneurial mindset affects positively and significantly the performance of SMEs including small and medium hotels (based on the following aspects: seeking opportunity, creativity, innovation, risk taking, pro-activeness, and alertness to that entrepreneurship which aims to generate new sustainable businesses, developing the ability to create, to organize a business, to manage risk and profit). Entrepreneurship in the tourism and hospitality industry was therefore recommended to boost competitiveness, entrepreneurial spirit and lead to increased economic productivity and economic development. 
Table 6: Respondents opinions on their status of their entrepreneurial mindset

\begin{tabular}{llll}
\hline Question & Emerging Themes & Comments & \\
\hline $\begin{array}{l}\text { In what other ways } \\
\text { would you describe }\end{array}$ & $\begin{array}{l}\text { Coming up with ideas which } \\
\text { are implemented in the }\end{array}$ opportunities. & \\
$\begin{array}{l}\text { yourself as far as the } \\
\text { entrepreneurial mindset }\end{array}$ & $\begin{array}{l}\text { Coming up with workshops } \\
\text { to address COVID- } 19\end{array}$ & Alertness on environmental issues affecting the \\
is concerned? & $\begin{array}{l}\text { challenges. } \\
\text { Rewarding the best staff at } \\
\text { the end of year. }\end{array}$ & $\begin{array}{l}\text { Encouragement by the management to innovate } \\
\text { or be creative. }\end{array}$ \\
\end{tabular}

The respondents were given the opportunity to mention the areas in entrepreneurial mindset they had improved on but were not captured in the close ended questions. Different hotels had different statements captured differently but the common nuances are recorded in table 6 . Some respondents indicated that they had come up with ideas which were implemented in the hotel meaning they were positive and recognizing opportunities. Other respondents had come up with workshops to address COVID- 19 challenges, meaning alertness on environmental issues affecting the hotel business. The other respondents indicated that the best staff members are rewarded at the end of year, thus encouragement by the management to innovate. Table 7 gives statements to answer the open-ended question on entrepreneurial mindset influence on hotel innovation.

Table 7: Entrepreneurial Mindset influence on hotel innovation

\begin{tabular}{llll}
\hline Question & Emerging Themes & Comments \\
\hline In your own & It has improved the hotel Creation of competitive advantage \\
opinion, how else & services & \\
do you think & After every service, the hotel Opportunity to maintain the best service and to \\
entrepreneurial & always contacts its customers to make corrections where necessary. \\
mindset & has & evaluate their satisfaction with \\
influenced hotel & the specific service being \\
innovation? & $\begin{array}{l}\text { offered. } \\
\text { The hotel has opened 2 Business growth } \\
\text { branches in two towns and } \\
\text { increased employees in one of } \\
\text { our branches by 10 }\end{array}$ \\
\hline
\end{tabular}

The respondents were given the opportunity to mention the areas in entrepreneurial mindset which have influenced hotel innovation but were not captured in the close ended questions. Different hotels had different statements captured differently but the common nuances are recorded in table 7. Some respondents indicated that entrepreneurial Mindset has improved the hotel services thus creating competitive advantage. Other respondents indicated that they contact customers after every service, to evaluate their satisfaction with the specific service being offered, this offers the hotels the opportunity to maintain the best service and to make corrections where necessary. The other respondents indicated that the hotel had opened 2 additional branches in two other towns and had increased employees in one of the branches by 10 meaning business growth. 


\subsection{Correlation between Entrepreneurial Mindset and Hotel Innovation}

Table 8: Correlation Analysis between Entrepreneurial Mindset and Hotel Innovation

\begin{tabular}{|llcc|}
\hline Correlations & & Hotel innovation & Entrepreneurial Mindset \\
\hline Hotel innovation & Pearson Correlation & 1 & \\
& Sig. (2-tailed) & & 239 \\
& $\mathrm{~N}$ & 239 & 1 \\
Entrepreneurial Mindset & Pearson Correlation & $.598^{* *}$ & \\
& Sig. (2-tailed) & 0.000 & 239 \\
& $\mathrm{~N}$ & 239 & \\
\hline
\end{tabular}

** Correlation is significant at the 0.01 level (2-tailed).

*Correlation is significant at the 0.05 level (1-tailed).

The results in Table 8 show that there is a positive and significant association between entrepreneurial mindset and hotel innovation $\left(\mathrm{r}=0.598^{* *}, \mathrm{p}=0.000\right)$. The strong $\mathrm{r}$ value of 0.598 indicates a value of greater than 0 which implies that entrepreneurial mindset as a linear variable has a positive association with hotel innovation. This implies that an increase in entrepreneurial mindset results to an increase in the hotel innovation. The findings agree with Adomako, Danso, Boso, and Narteh, (2018) who concluded that increase in the levels of entrepreneurial alertness affect new venture performance increase. Entrepreneurial alertness is too narrow a scope to infer a venture performance. Tajeddini, Martin and Ali (2020) also posit that in an uncertain, dynamic environment a higher level of risk and entrepreneurial orientation (entrepreneurial strategymaking) benefit business performance especially when coupled with strong business and social networks. According to Kimathi (2020), creativity, innovation, awareness about support services and self-efficacy has positive and significant effect on performance of enterprises in Kenya. Propensity to take risk was positively but insignificant related to performance. Thus, Kimathi (2020) concluded that entrepreneurial mindset influenced performance of small and medium enterprises in Kenya and entrepreneurs with creativity, innovativeness, risk taking, awareness and self-efficacy outperform their competitors and steer their enterprises to profitability.

\subsection{Regression Analysis for Entrepreneurial Mindset}

The study also sought to investigate the causal effect of the independent variable on the dependent variable. The findings represent the model of fitness, ANOVA tests and the regression of coefficients.

Table 9: Model of Fitness for Entrepreneurial Mindset

\begin{tabular}{|lcccc|}
\hline Model & R & R Square & Adjusted R Square & Std. Error of the Estimate \\
\hline 1 & $.598 \mathrm{a}$ & 0.358 & 0.355 & 0.367954 \\
\hline
\end{tabular}

a Predictors: Constant, Entrepreneurial Mindset

The results in Table 9, present the fitness of regression used in explaining the study phenomena. Entrepreneurial mindset is essential in the hotel innovation. This is evident, as shown by the $\mathrm{R}$ square value which 0.358 . This implies that entrepreneurial mindset explains $35.8 \%$ of hotel innovation. 
Table 10: ANOVA for Entrepreneurial Mindset

\begin{tabular}{llcccc}
\hline & Sum of Squares & df & Mean Square & F & Sig. \\
\hline Regression & 17.871 & 1 & 17.871 & 131.995 & $.000 \mathrm{~b}$ \\
Residual & 32.087 & 237 & 0.135 & & \\
Total & $\mathbf{4 9 . 9 5 8}$ & $\mathbf{2 3 8}$ & & & \\
\hline
\end{tabular}

a Dependent Variable: Hotel innovation

b Predictors: Constant, Entrepreneurial Mindset

The results in Table 10 show that the model was statistically significant implying that entrepreneurial mindset affects hotel innovation. This is further supported by the $\mathrm{F}$ statistic 131.995 where the value was greater than the critical value at 0.05 significance level, $\mathrm{F}$ statistic $=$ $131.995>\mathrm{F}_{\text {critical }}=3.841(1,237)$.

\section{Table 11: Regression of coefficients for Entrepreneurial Mindset}

\begin{tabular}{lccccc}
\hline Variable & $\boldsymbol{\beta}$ & Std. Error & Beta & t & Sig. \\
\hline Constant & 1.512 & 0.191 & & 7.930 & 0.000 \\
Entrepreneurial Mindset & 0.590 & 0.051 & 0.598 & 11.489 & 0.000 \\
\hline
\end{tabular}

a Dependent Variable: Hotel innovation

Regression of the coefficients results in Table 11, revealed that entrepreneurial mindset and hotel innovation by 1-3 star rated hotels in Kenya have a positive and significant relationship $(\boldsymbol{\beta}=0.590, \mathrm{p}=0.000)$. This implies that improvement in 1 unit of the aspects related to entrepreneurial mindset improves hotel innovation by 1-3 star rated hotels in Kenya by 0.590 units. The findings are consistent with previous findings indicating that entrepreneurial spirit fosters the development and enhancement of innovative skills (Alnawas \& Hemsley-Brown 2019; Ghantous \& Alnawas 2020). Indeed, market orientation has an effect on the project capability since it allows for the advancement of promotional competencies and the achievement of positive marketing achievements (Revilla-Camacho et al., 2020). Additionally, other characteristics such as collaborative partnerships (Pongsathornwiwat et al., 2019) and learning orientation (Nair, 2019) boost organizational innovation capabilities. Likewise, according to Jemal (2020), entrepreneurial mindset affects positively and significantly the performance of SMEs including small and medium hotels (based on the following aspects: seeking opportunity, creativity, innovation, risk taking, pro-activeness, and alertness to that entrepreneurship which aims to generate new sustainable businesses, developing the ability to create, to organize a business, to manage risk and profit). Entrepreneurship in the tourism and hospitality industry was therefore recommended to boost competitiveness, entrepreneurial spirit and lead to increased economic productivity and economic development.

\subsection{Hypothesis Testing}

The acceptance/rejection format was that, if the $\mathrm{p}$-value is less than 0.05 , the $\mathrm{H}_{0}$ is not accepted but if it's greater than 0.05 , the $\mathrm{H}_{0}$ fails to be rejected. The null hypothesis $\mathrm{H}_{0}$ : was that the effect of entrepreneurial mindset on innovation by 1-3 stars rated hotels in Kenya is not statistically significant. 
Table 12: Hypotheses Test Results

\begin{tabular}{|c|c|c|c|c|}
\hline Research objective & Tested Hypothesis & Rule & P-value & $\begin{array}{l}\text { Results of the } \\
\text { hypothesis }\end{array}$ \\
\hline $\begin{array}{l}\text { To assess the effect } \\
\text { of entrepreneurial } \\
\text { mindset on } \\
\text { innovation by } 1-3 \\
\text { star rated hotels in } \\
\text { Kenya. }\end{array}$ & $\begin{array}{l}\mathbf{H}_{\mathbf{0}} \text { : The effect of } \\
\text { Entrepreneurial } \\
\text { mindset on innovation } \\
\text { by 1-3 stars rated hotels } \\
\text { in Kenya is not } \\
\text { statistically significant. }\end{array}$ & $\begin{array}{l}\text { When } \mathrm{p} \text { value is } \\
\text { less than } 0.05 \text {, } \\
\text { reject the null } \\
\text { hypothesis }\end{array}$ & 0.020 & Rejected \\
\hline
\end{tabular}

Based on the multiple regression findings (Table 11), alternative hypothesis was rejected since the $\mathrm{P}$ values were less than 0.05 and thus, there is a significant effect between entrepreneurial mindset and innovation by 1-3 stars rated hotels in Kenya.

\subsection{SUMMARY, CONCLUSION AND RECOMMENDATION}

\subsection{Summary of the findings}

\subsubsection{Entrepreneurial Mindset and Hotel Innovation by 1-3 Star Rated Hotels in Kenya}

The objective was to assess the effect of entrepreneurial mindset on innovation by 1-3 star rated hotels in Kenya. To achieve this objective, the respondents indicated their level of agreement to various statements on their entrepreneurial mindset. The study hypothesized that the effect of Entrepreneurial mindset on innovation by 1-3 stars rated hotels in Kenya is not statistically significant.

The findings showed that there is a positive and significant association between entrepreneurial mindset and hotel innovation $\left(\mathrm{r}=0.598^{* *}, \mathrm{p}=0.004\right)$. The $\mathrm{r}$ value of 0.598 indicates a value of greater than 0 which implies that entrepreneurial mindset as a linear variable has a positive association with hotel innovation. This implies that an increase in entrepreneurial mindset results to an increase in the hotel innovation. These findings were supported by the responses from the questionnaire where the majority of the respondents described themselves as entrepreneurial minded towards hotel innovation. The regression findings revealed that entrepreneurial mindset and hotel innovation by 1-3 star rated hotels in Kenya are positively and significantly related $(\boldsymbol{\beta}=0.302, \mathrm{p}=0.020)$. This led to the rejection of the alternative hypothesis that; there is no significant relationship between entrepreneurial mindset and hotel innovation by 1-3 star rated hotels in Kenya. These findings are consistent with Njeru (2012) who indicated that there was a positive relationship between entrepreneurial alertness and innovative performance. There was also notable relationship between Entrepreneurs' characteristic and innovativeness, creativity and business alertness and a positive relationship between innovativeness and business performance. The findings also agree with Adomako, Danso, Boso, and Narteh, (2018) who concluded that increase in the levels of entrepreneurial alertness affects new venture performance increase.

\subsection{Conclusions}

The study concludes that 1-3 star rated hotels in Kenya have strived to improve their innovative ability since they have shown consistency in seeking information on new business ideas in the hotel sector; access of information on new business ideas in the hotel sector; identifying and choosing most promising business opportunities and execution of the most promising business 
opportunity. In addition, the managers view changes in the hotel sector as precursors for new business opportunities implying the resilient entrepreneurial mindset.

\subsection{Recommendations}

Based on the study findings, the study recommends the hotel entrepreneurs to be proactive in seeking new product ideas and customer product information which will in turn enable them create ideas on coming up with innovative products.

\section{REFERENCES}

Adomako, S., Danso, A., Boso, N., \& Narteh, B. (2018). Entrepreneurial alertness and new venture performance: Facilitating roles of networking capability. International Small Business Journal, 36(5), 453-472.

Allen, D. S. (2016). The impact of shortening a long survey on response rate and response quality (Doctoral dissertation). Retrieved from https://scholarsarchive.byu.edu/etd/5968?utm_source=scholarsarchive.byu.edu\%2Fetd\%2 F5968\&utm_medium=PDF\&utm_campaign=PDFCoverPages.

Alnawas, I., \& Hemsley-Brown, J. (2019). Market orientation and hotel performance: investigating the role of high-order marketing capabilities. International Journal of Contemporary Hospitality Management.

Ardichvili, A., Cardozo, R., \& Ray, S. (2003). A theory of entrepreneurial opportunity identification and development. Journal of Business venturing, 18(1), 105-123.

Backman, M., Johan, K, J., and Öner, Ö (2017). Innovation in the hospitality industry: Firm or location? Sage Journals. https://doi.org/10.1177/1354816617715159. Vol. 23, Issue 8,2017 .

Baporikar, N. (2014). Innovation in the 21st century organization. In Transcultural Marketing for Incremental and Radical Innovation (pp. 339-365). IGI Global.

Bober, M. M. (1965). Karl Marx's Interpretation of History: A study of the central thesis of the Marx-Engels doctrine of social evolution. New York: The Norton Library.

Covin, J. G., \& Slevin, D. P. (1989). Strategic management of small firms in hostile and benign environments. Strategic management journal, 10(1), 75-87.

Cox, K. (2016). Entrepreneurial Alertness, Metacognition, and Opportunity Identification. Florida Atlantic University.

Davis, M. H., Hall, J. A., \& Mayer, P. S. (2016). Developing a new measure of entrepreneurial mindset: Reliability, validity, and implications for practitioners. Consulting Psychology Journal: Practice and Research, 68(1), 21.

Dzhandzhugazova, E. A., Blinova, E. A., Orlova, L. N., \& Romanova, M. M. (2016). Innovations in hospitality industry. International Journal of Environmental and Science Education, 11(17), 10387-10400.

Ebner, A. (2005). Hayek on entrepreneurship: Competition, market process and cultural evolution. Entrepreneurship, money and coordination, 131-49. 
Ertuna, B., Karatas-Ozkan, M., \& Yamak, S. (2019). Diffusion of sustainability and CSR discourse in hospitality industry. International Journal of Contemporary Hospitality Management.

Foster, C., \& Graham, M. (2015). The Internet and Tourism in Rwanda: Value Chains and Networks of Connectivity-Based Enterprises in Rwanda.

Gaglio, C. M., \& Katz, J. A. (2001). The psychological basis of opportunity identification: Entrepreneurial alertness. Small business economics, 16(2), 95-111.

Ghantous, N., \& Alnawas, I. (2020). The differential and synergistic effects of market orientation and entrepreneurial orientation on hotel ambidexterity. Journal of Retailing and Consumer Services, 55, 102072.

Jemal, S. (2020). Effect Of Entrepreneurial Mindset And Entrepreneurial Competence On Performance Of Small And Medium Enterprise, Evidence From Litrature Review. International Journal of Management \& Entrepreneurship Research, 2(7), 476491.

Karlesky, M. J. (2015). Identifying entrepreneurial opportunities: Cognition and categorization in nascent entrepreneurs (Doctoral dissertation).

Katz, J., \& Gartner, W. B. (1988). Properties of emerging organizations. Academy of management review, 13(3), 429-441.

Kaya, P. H. (2015). Joseph A. Schumpeter's Perspective on Innovation. International Journal of Economics, Commerce and Management United Kingdom, III (8), 25-37. Retrieved from http://ijecm.co.uk/

Khandwalla, P.N. (1977) The Design of Organizations. Harcourt Brace Jovanovich, New York.

Kimathi, B. M. (2020). Entrepreneurial Mindset and Performance of Small and Medium Enterprises in Kenya (Doctoral dissertation, JKUAT-COHRED).

Kirzner, I. M. (1997). Entrepreneurial discovery and the competitive market process: An Austrian approach. Journal of economic Literature, 35(1), 60-85.

Lucky, E. O. I., \& Minai, M. S. (2011). The conceptual framework of entrepreneur and selfmanagement. International Journal of Business and Social Science, 2(20).

Lumpkin, G. T., \& Dess, G. G. (1996). Clarifying the entrepreneurial orientation construct and linking it to performance. Academy of management Review, 21(1), 135-172.

Mattsson, J., \& Orfila- Sintes, F. (2014). Hotel innovation and its effect on business performance. International Journal of Tourism Research, 16(4), 388-398.

Marx, K. (1973). Karl Marx on society and social change: With selections by Friedrich Engels. University of Chicago Press.

McMullen, J. S., \& Kier, A. S. (2016). Trapped by the entrepreneurial mindset: Opportunity seeking and escalation of commitment in the Mount Everest disaster. Journal of Business Venturing, 31(6), 663-686. 
Meira, J. V. D. S., Dos Anjos, S. J. G., \& Falaster, C. D. (2019). Innovation and performance in the hotel industry. Journal of Quality Assurance in Hospitality \& Tourism, 20(2), 185205.

Miller, D., \& Friesen, P. H. (1982). Structural change and performance: Quantum versus piecemeal-incremental approaches. Academy of management Journal, 25(4), 867-892.

Murimi, G. S., Moses, K., \& Eric, N. (2019). Role Of Technological Innovation On The Performance Of Small And Medium Enterprises (Smes): A Survey Of Hotels In Nairobi. International Journal of Business Management and Finance, 1(1).

Naia, A., Baptista, R., Januário, C., \& Trigo, V. (2014). A systematization of the literature on entrepreneurship education: challenges and emerging solutions in the entrepreneurial classroom. Industry and Higher Education, 28(2), 79-96.

Nair Ph D, G. K. (2019). Dynamics of learning orientation, innovativeness, and financial performance of the hotel industry. Journal of Hospitality Financial Management, 27(1), 4.

Njeru, P. W. (2012). The effect of entrepreneurial mind set on the performance of manufacturing Businesses in Nairobi industrial area. Unpublished PhD thesis, Jomo Kenyatta University of Agriculture and Technology, Nairobi, Kenya.

Orfila-Sintes, F., Crespi-Cladera, R., \& Martínez-Ros, E. (2005). Innovation activity in the hotel industry: Evidence from Balearic Islands. Tourism Management, 26(6), 851-865.

Phan, P. H. (2004). Entrepreneurship theory: Possibilities and future directions. Journal of Business Venturing 19 (2004) 617 - 620.

Pongsathornwiwat, A., Jeenanunta, C., Huynh, V. N., \& Udomvitid, K. (2019). Can collaborative relationship stimulate innovation capability and improve performance in the hospitality industry? International Journal of Innovation and Learning, 26(3), 321-342.

Rae, D., \& Wang, C. L. (Eds.). (2015). Entrepreneurial learning: new perspectives in research, education and practice. Routledge.

Rauch, A., Wiklund, J., Lumpkin, G. T., \& Frese, M. (2009). Entrepreneurial orientation and business performance: An assessment of past research and suggestions for the future. Entrepreneurship theory and practice, 33(3), 761-787.

Revilla- Camacho, M. Á., Palacios- Florencio, B., Garzón, D., \& Prado- Román, C. (2020). Marketing capabilities and innovation. How do they affect the financial results of hotels?. Psychology \& Marketing, 37(3), 506-518.

Rindfuss, R. R., Choe, M. K., Tsuya, N. O., Bumpass, L. L., \& Tamaki, E. (2015). Do low survey response rates bias results? Evidence from Japan. Demographic Research, 32, 797-828.

Sabiiti, D. (2020, June 15). Rwanda's Tourism Seeks Innovative Minds to Recover from Covid19 Shock. KT PRESS. https://www.ktpress.rw/2020/05/rwandas-tourism-seeksinnovative-minds-to-recover-from-covid-19-shock/ 
Safali, S., \& Akpunar, B. (2020). Validity and Reliability Study of Academic Self-Efficacy Scale for Faculty Members. Advances in Language and Literary Studies, 11(4), 21-29.

Schumpeter, J. (1934). The theory of economic development. Boston: Harvard University Press.

Sekaran, U., \& Bougie, R. (2019). Research methods for business: A skill building approach. john wiley \& sons.

Simon, M., \& Goes, J. (2016). Reliability and validity in qualitative studies (Doctoral dissertation, Dissertation).

Sudrajat, D. (2015). The Relationships among Leadership, Entrepreneurial Mindset, Innovation and Competitive Advantage (A Conceptual Model of Logistics Service Industry). Binus Business Review, 6(3), 477-485.

Tajeddini, K., Martin, E., \& Ali, A. (2020). Enhancing hospitality business performance: The role of entrepreneurial orientation and networking ties in a dynamic environment. International Journal of Hospitality Management, 90, 102605.

Wadongo, B., Odhuno, E., Kambona, O., \& Othuon, L. (2010). Key performance indicators in the Kenyan hospitality industry: a managerial perspective. Benchmarking: An international journal.

Wanjiku, E. M. (2018). The Effect of Innovation on Sustainable Competitive Advantage (Client Satisfaction) In the Hospitality Industry in Kenya: A Case Study of the Safari Park Hotel. URI: http://erepo.usiu.ac.ke/11732/3943.

Wikhamn, W., Armbrecht, J., \& Wikhamn, B. R. (2018). Innovation in Swedish hotels. International Journal of Contemporary Hospitality Management.

World Bank, (2018). An Economic Assessment of Tourism in Kenya: Standing Out From The Herd.

http://documents1.worldbank.org/curated/en/573241507036299777/pdf/AUS16758-WPREVISED-P156577-OUO-9-Tourism-report-FINAL.pdf 